\title{
Ureter Neoplasm
}

National Cancer Institute

\section{Source}

National Cancer Institute. Ureter Neoplasm. NCI Thesaurus. Code C3427.

A benign or malignant neoplasm that affects the ureter. 